\title{
Marriage in the New Testament and in the Early Church ${ }^{2}$
}

\author{
by WILLY RORDORF
}

Professor of Patristics and Early Church History in the Theological Faculty of the University of Neuchâtel, Switzerland

hristian ethics is not a matter of fixed and unchangeable laws. If
we are to study its history we must follow a story of development should shock us as though its development were something that puts in question its changeless value. On the contrary, its value is confirmed by its evolution, because Christian ethics is essentially dynamic. From this intrinsic dynamism we are constantly pushed forward. As Christians we live under one commandment, the commandment of love given by Jesus himself which is the centre of the dynamism. If Christian ethics becomes static, it contradicts its very nature. Far from being a tradition that is to be upheld from age to age, Christian ethics is the means of criticising the traditions of every age and a means of searching lines of development for the future.

Inștead of imitating, with my native Germanic thoroughness, one of the surgical dissections of Kittel's 'Theological Word Book', I would rather study the New Testament doctrine of marriage by means of four questions; then in the following section we shall ask the same questions of the patristic literature. First I propose to investigate the relation of marriage and eschatology; then I propose to study the theme of adultery, divorce, and second marriages; thirdly, there is the question of the attitude toward women and toward sexuality; and, finally, I would like to ask whether marriage is a sacrament. ${ }^{2}$

\section{Marriage and eschatology}

Jesus preached the coming of the kingdom of God. Whoever hears the preaching is faced by the eschatological challenge to repent and obey.

${ }^{1}$ Special Lecture in Theology, delivered at University of London King's College on 21 November 1968. Translation by Rev. H. O. Old.

2 There are, of course, a great number of studies on marriage in the New Testament. See the bibliographies in $\mathrm{H}$. Baltensweiler, Die Ehe im Neuen Testament. Exegetische Untersuchung über Ehe, Ehelosigkeit und Ehescheidung, Zürich 1967; E. Schillebeeckx, Le mariage, Paris I966, I; Christliche Ehe und getrennte Kirchen (Oekumenische Beihefte, I), Freiburg/ Switzerland r 968,96 f.; H. Greeven, J. Rattinger, R. Schnackenburg, R. D. Wendland, Theologie der Ehe, Göttingen 1969 . 
God's call to men in the person of Jesus puts this world and all its structures in question, but also it sends men into this same world in a ministry of reconciliation. This double movement of judgment and reconciliation is forcefully reflected in both the New Testament's doctrine of marriage and in its ethics of marriage. We shall study first one movement and then the other, but we shall not lose sight of the fact that the two movements are dynamically related. Precisely here is the originality of Jesus. The question of whether a particular interpretation of Christian ethics has been able to maintain these two movements in a dynamic relationship will enable us to evaluate its claim to being truly Christian.

In certain texts the eschatological questioning of marriage has not risen above a mere repeating of some of the images of Jewish apocalyptic literature: because the end of time approaches, it is not good, it is even perhaps tragic, to be married.

'And alas for those who are with child and for those who give suck in those days!' (Mk. xiii. I 7)

'For in those days before the flood they were eating and drinking, marrying and giving in marriage, until the day when Noah entered the ark, and they did not know until the flood came, and swept them all away, so will be the coming of the Son of man.' (Mt. ii. $33 \mathrm{ff}$.)

We find similar teaching in Jewish apocalyptic. ${ }^{1}$ But this is not the only angle from which the Gospels question marriage: there is that call to follow Christ which demands that a disciple put his family obligations behind him and give himself totally to God:

'If any man comes to me and does not hate his own father and mother and wife and children ... he cannot be my disciple' (Lk. xiv. 26). ${ }^{2}$

The joy of finding the pearl of great price and the treasure hidden in the field $^{3}$ would so fill the disciple that he would be willing to sacrifice all the rest. Surely it is in the context of the joy of being completely free and open to God's will that we are to understand Christ's saying about eunuchs:

'For there are eunuchs who have been so from birth, and there are eunuchs who have been made eunuchs by men, and there are eunuchs who have made themselves eunuchs for the kingdom of heaven' (Mt. xix. 12). 4

Unlike Qumran, we do not have here some sort of obligatory celibacy for all the faithful, but rather a special spiritual gift given by God. ${ }^{5} \mathrm{It}$ is these who rejoice in the presence of the bridegroom ${ }^{6}$ and who await the wed-

${ }^{1}$ Syriac Apocalypse of Baruch, $\mathbf{x}$.

${ }^{3}$ Mt. xiii. 44 f.

2 Cf. Lk. xiv. 20; xx. 34-36; Mt. viii. 22 par.

$4 \mathrm{Cf}$. H. Baltensweiler, op. cit., 107.

5 Cf. H. Braun, Qumran und das Neue Testament, Tübingen 1966, ii. 292 where the same difference is stated between Qumran and Paul: at Qumran, celibacy was required, for Jesus and Paul it was not obligatory.

'Mk. ii. 19 par.; cf. Jn. ii. I ff.; xix. 34 ff. 
MARRIAGE IN THE NEW TESTAMENT AND EARLY GHURGH

ding feast of the Lamb. ${ }^{1}$ Their whole apostolic work is done in this perspective. $^{2}$

We find that the apostle Paul subjects marriage to the same eschatological perspective. One has often done Paul an injustice in failing to recognise the eschatological context of his so-called negative remarks about marriage. ${ }^{3}$ Actually this eschatological context is essential for understanding the attitude of Paul, who says:

'I think that in view of the impending distress it is well for a person to remain as he is ... I mean brethren the appointed time has grown very short; from now on, let those who have wives live as though they had none, ... for the form of this world is passing away ... I want you to be free from anxieties. The unmarried man is anxious about the affairs of the Lord, how to please the Lord; but the married man is anxious about worldly affairs' (I Cor. vii. 26, 29, 31 b-33a).

One may conclude therefore that celibacy for the sake of the Kingdom of God is a possible, legitimate and honourable way of living the Christian life, and that Paul is a faithful interpreter of a tradition that goes back to the preaching of Jesus himself. It might be well for the Christian Churches to remember that marriage belongs to that 'form of this world which is passing away'.4

\section{Adultery, divorce and second marriages}

Even though both Jesus and Paul treat marriage as being of penultimate importance rather than of ultimate importance, this penultimate importance is, nevertheless, of profound importance. ${ }^{5}$ I do not think I would be mistaken if I were to claim that the common denominator of all the sayings of Jesus about marriage is the commandment of total love towards one's neighbour. The human love of man and wife belong to the natural created order, ${ }^{6}$ and, therefore, it is important that Christian love enter into it. Agape, the self-giving love which is the true Christian love ought not to be confused with sexual love, to be sure, but certainly Christian love ought to infuse sexual love; Christian love ought to animate sexual love, and that is why it is perfectly appropriate to read I Cor. xiii

1 Mt. xxii. 1-14 par.; xxv. 1-12; and especially Rev. xix. 7-9; xxi. 2, 9; xxii. 17; also xiv. 4 .

${ }^{2}$ Jn. iii. 29; II Cor. ii. 2.

s See for instance $\mathrm{H}$. Preisker, Christentum und Ehe in den ersten drei Fahrhunderten, Berlin 1927, 123 ff.; G. Delling, Paulus' Stellung zu Frau und Ehe, Stuttgart 1931. Cf, the critique by $\mathrm{H}$. Baltensweiler, op. cit., $150 \mathrm{ff}$. and especially $167 \mathrm{ff}$.

- H. Baltensweiler, op. cit., 265 makes the following remark in this respect: 'Es scheint, dass die Einschätzung der ehelos lebenden Gemeindeglieder in den protestantischen Kirchen einen untrüglichen Gradmesser darstellt für die Rolle, welche die Endzeit in unserm Glauben spielt'. Cf. also M. Thurian, Mariage et célibat, Neuchâtel 1964 .

5 E. Stauffer, in Theologisches Wörterbuch zum Neuen Testament, i. 649 says justly: 'Er (Jesus) weiss um das Recht, um den Sinn, um die Herrlichkeit der Ehe, wie er um die Herrlichkeit der Blumen weiss, die doch morgen vergehen'.

${ }^{6} \mathrm{Mk}$. x. $6 \mathrm{ff}$. 
at the blessing of weddings. If it is the responsibility of all Christians to practise agape, then certainly married couples ought to practise it toward each other.

The commandment of love applied to concrete life situations could not help but make radical demands.

"You have heard that it was said "you shall not commit adultery". But I say unto you that every one who looks at a woman lustfully has already committed adultery with her in his heart' (Mt. v. 27-28)..$^{1}$

Divorce is looked upon as an easy way out and as such it is criticised by Jesus according to the stringent requirement to love. Moses had permitted divorce, only because of the hardness of men's hearts, but 'whom God has joined together let no man put apart' (Mk. x. 5, 9 par.). Jesus does not decree the indissolubility of marriage as though it were some sort of ontological union, but rather he speaks of the ethical imperative of a love which continues to give of itself without reserve even until the very end. Needless to say, this is not very consistent with divorce and remarriage. ${ }^{2}$

'Whoever divorces his wife and marries another, commits adultery against her; and if she divorces her husband and marries another, she commits adultery' (Mk. x. IIb-12). ${ }^{3}$

The apostle Paul takes up the same position when, perhaps referring to this very saying of Jesus, he says:

'To the married I give charge, not I but the Lord, that the wife should not separate from her husband ... and that the husband should not divorce his wife' (I Cor. vii. IO-I I).

The famous verses in the Gospel of Matthew (v. 32; xix. 9) with which some would soften Christ's radical rejection of divorce by allowing it in the case of adultery, have provoked a discussion much too involved for us to take up in detail. ${ }^{4}$ We will simply indicate in the most general way the lines on which the discussion has gone. On the one hand, there are those who have seen this exception as an expression of the circle of Christians which produced the Gospel of Matthew and which did not find an echo in other strata of the literature of the New Testament and the ancient Church, ${ }^{5}$ or, on the other hand, some explain the text of Matthew in line with Paul (I Cor. vii. II) and the unanimous opinion of the Church

1 There are Jewish parallels to this radical attitude: cf. H. Preisker, op. cit., 8o; H. Braun, op. cit., 292.

2 A similar position is taken by G. Bornkamm, Geschichte und Glaube, Munich 1968, i. 56 ff.; H. Greeven, in Zeitschrift für evangelische Ethik, i (1957), I 7 .

${ }^{3}$ Note that here the woman is placed on the same level as the man.

4 E. Schillebeeckx (op. cit., 151 ff.) gives a good summary of the different interpretations.

${ }^{5}$ This is especially the case in the interpretation of porneia as meaning illicit marriages according to Lev. xviii (thus J. Bonsirven, H. Baltensweiler, P. Bonnard). But Mt. xix. 3 reflects rather the discussion between Hillel and Shammai where porneia means 'adultery' in the traditional sense. 
Fathers. ${ }^{1}$ I have to admit that I find the second approach more convincing. In this case it would seem to me that the Gospel of Matthew allows for the separation of a married couple because of the immorality of one or the other, but it does not allow the remarriage of either.

One should also say something of Paul's acceptance of the division of a mixed marriage in the event that the non-Christian demands such a separation (I Cor. vii. 15). To understand this we must understand the whole argument of the seventh chapter of I Corinthians. ${ }^{2}$ Challenged by the ascetics of Corinth, Paul makes a defence of marriage. Marriage is good for several different reasons. In the first place marriage is a protection against immorality. ${ }^{3}$ Secondly, marriage has a certain positive value aside from procreation. Paul does not follow post-exilic Judaism in finding that the value of marriage is to be found exclusively in giving birth to children. 'The husband should give to his wife her conjugal rights, and likewise the wife to her husband. For the wife does not rule over her own body, but the husband does; likewise, the husband does not rule over his own body, but the wife does' (I Cor. vii. 3-4).

Not even prayer is to be used as a pretext for abstaining from sexual relations. ${ }^{4}$ Thirdly, Paul understands marriage under the category of sanctification: the married couple being members of the body of Christ, become one flesh, and mutually sanctify themselves in Christ. It is because of this that their children too are holy, and this is even the case if one of the partners is not a Christian. The believer sanctifies the non-believer. ${ }^{5}$ There is an exception, however:

'But if the unbelieving partner desires to separate, let it be so; in such a case the brother or sister is not bound. For God has called us to peace' (I Cor, vii. I5).

There is, then, in mixed marriages the possibility of separation if the nonChristian refuses to live with the Christian. ${ }^{6}$ It is not said in the text itself whether the Christian separated from a marriage partner under such circumstances may marry another. It seems to me that Paul's reason for allowing the division of a mixed marriage is closely related to the sayings of Jesus to the effect that one must leave one's family and loved ones for the sake of the Kingdom of God. ${ }^{7}$ Certainly, if we are to recognise this

1 Cf. J. Dupont, Mariage et divorce dans l'Evangile, Bruges 1959, 161-220; E. Schillebeeckx, op. cit., I59; R. Schnackenburg, Die sittliche Botschaft des Neuen Testaments, and ed. Munich 1962, 103 ff. See now also F. J. Leenhardt, in Revue de theol. et de philos., ci (1969), 31-40.

${ }^{2}$ For the following, see H. Baltensweiler, op. cit., $153 \mathrm{ff}$; i 9 I $\mathrm{ff}$; ; also $197 \mathrm{ff}$.

${ }^{3}$ I Cor. vii. 2, 5, 9; cf. vii. $36 \mathrm{ff}$. 4 I Cor. vii. $5 \mathrm{f}$.

${ }^{5}$ I Cor. vii. 12 ff. St. Paul is, then, much more optimistic with regard to mixed marriage than post-exilic Judaism was: see especially the interpretation of $I$ Cor. vii. I6 given by J. Jeremias, in Neutestamentliche Studien für Rudolf Bultmann, Tübingen 1954, 255260. Cf. also I Peter iii. I $\mathrm{f}$.

- A similar, but extreme case, is described in I Cor. vi. I5 ff.: a Christian could marry a prostitute; but he has no right to have intercourse with her if she does not want to marry him. Cf. the interdiction of fornication in I Thess. iv. $3,7$.

${ }^{7}$ Cf. Lk. xviii. 29 f. See H. Baltensweiler, op. cit., 193. 
eschatological basis of Paul's teaching, we must recognise how inconsistent a remarriage would be with his understanding of the problem.

There is really only one case where Paul permits a remarriage and that is when one of the marriage partners dies; even then Paul says he would rather see one remain a widow or a widower. ${ }^{1}$ The second marriage of a Christian who has lost a husband or wife by death should very definitely be 'in the Lord', that is, one should marry another Christian and avoid the dangers of a mixed marriage. ${ }^{2}$

\section{Attitude toward women}

There is a whole area of marriage morality, which, it would seem to me, is not really derived from the essence of the Christian Gospel. It is found, to be sure, in the New Testament, but its sources are not so much to be found in the message of Jesus or any of his apostles as in the general environment of the classical world. This area of New Testament ethics is often referred to by the German word Haustafeln, that is, those lists of laws for the family and the running of the house which we might simply call domestic duties.

These lists of domestic duties reflect the social structures and the rules of good conduct of their age. ${ }^{3}$ The Christian message is not interested in changing them. Rather it teaches the Christian to live 'in the Lord' within the ordinary framework of his culture. It is among these relations between civil authorities and ordinary citizens, between master and slave, between parent and child, that we find the ideal for the relationship of man and wife, and this relationship is stated in about the same terms as we find it in postexilic Judaism. And here this concern, just as for the Jews of the Hellenistic period, has a strong apologetic interest. One is to lead an exemplary life as a witness to the heathen:

'Likewise you wives, be submissive to your husbands, so that some, though they do not obey the Word, may be won without a word by the behaviour of their wives, when they see your reverent and chaste behaviour. Let not yours be the outward adorning with the braiding of hair, decoration of gold, and wearing of robes, but let it be the hidden person of the heart, with the imperishable jewel of a gentle and quiet spirit, which in God's sight is very precious' (I Peter iii. I-4).4

In all the various versions of these lists of domestic duties, both in biblical and patristic literature, we find that a woman's submission to her husband is the central theme. ${ }^{5}$ What is amazing is how this aspect of

${ }^{1}$ I Cor. vii. 39 f.; vii. 8 f.; Rom. vii. 2-3. Remarriage is excluded for bishops, deacons and widows: I Tim. iii. 2, 12; v. 9; Titus i. 6.

2 I Cor. vii. 39; cf. II Cor. vi. I 4 ff.

${ }^{3}$ Cf. K. Weidinger, Die Haustafeln. Ein Stück urchristlicher Paränese, Leipzig I928, and

D. Schroeder, Die Haustafeln des Neuen Testaments, Hamburg 1959.

4 Cf. Titus ii. 3-5; I Tim. ii. 9-10; I Clem. xxi. 7.

${ }^{5}$ Col. iii. 18; Eph. v. 22, 24, 33; Titus ii, 5; I Tim. ii, I ; I Peter iii. I, 5-6; I Clem. i. 3 . 
classical culture has so unsuspectingly been drawn into the Christian tradition. The apostle Paul even makes an attempt to base woman's submission to man on an anthropological argument. In I Cor. xi he tries to prop up the rather curious dictum that women must wear veils in church. According to Paul, man is made in the image of God while woman is a reflexion of man. ${ }^{1}$ But one almost senses that Paul is as uncomfortable with his argument as we are. This is especially evident when he says,

'Nevertheless in the Lord woman is not independent of man nor man of woman; for a woman was made from man, so man is now born of woman' (I Cor. xi. I I-12).

This remark obviously weakens his whole argument.

I am not criticising the primitive Church for having uncritically adopted the social structures and patterns of conduct of its environment. In the first place, the eschatological hope of the first Christians did not make them especially ready to make sweeping reforms in a world that was. about to pass away. Their manner of doing things can also be understood as being in accord with the commandment of love. Man of course cannot live in a vacuum, even while awaiting the eschaton. He has need of structures and concrete rules of conduct. These patterns are not cast away by the commandment of love, but rather they are given a 'direction' and a 'quality', to use the terms of that great Englishman respected by the whole theological world, Professor C. H. Dodd. ${ }^{2}$ Indeed, sometimes it is necessary to change Christian ethical standards on account of the same commandment of love when the social structures on which these standards were based and to which they spoke have changed. The new social structures will need a new set of Christian ethics and a new Christian social criticism. It would be anachronous to try to realise some ethical standards of New Testament times in the twentieth century. Worse than an anachronism, it would be an inhuman legalism, and that certainly was not the intention of the exhortations of the first Christians. In our society it would make no sense to preach the obedience of slaves to their masters. In fact, if anyone were to try it we would consider his preaching intolerable. It is the same with the submission of women to their husbands. It would be foolish for the Church to teach such a thing to-day. ${ }^{3}$

\section{The sacramentality of marriage}

On the basis of the New Testament it is difficult to claim that marriage is a sacrament. It is not so much a case of there being no so-called 'Dominical institution' of a supposed sacrament of marriage such as one is accus-

1 I Tim. ii. I I $\mathrm{ff}$. goes even further in saying that because the fall of man was caused by his wife, she must be submissive to her husband. This position is already taken by Jesus ben Sirach, xxv. 24, and Philo, De officiis mundi, \& 165 .

2 In his book Gospel and Law, 6th ed. Cambridge 1965 .

${ }^{8}$ There are, of course, few to say it frankly; one of them is E. Schillebeeckx, op. cit., $173 \mathrm{ff}$., especially 191. 
tomed to claim for Baptism and the Lord's Supper. The fact that weighs so heavily against considering marriage as a sacrament is simply that we have no evidence that there was any sort of nuptial blessing presided over by the ministers of the Church, either in the literature of the New Testament or in the earliest patristic literature. ${ }^{1}$

Naturally I expect someone to ask about the famous passage in Ephesians, where the author quotes the creation story to the effect that a man shall be joined to his wife and that the two shall become one flesh, and then comments on the passage:

'This is a great mystery, and I take it to mean Christ and the Church' (Eph. v. 32).

The author of Ephesians sees, therefore, in the biblical account of the first couple a type of the relation of Christ to the Church. This is one possible interpretation, among others of course, which might be defended. Our author takes over here the prophetic tradition which speaks of the marriage of Yahweh and his people. As we see in the same passage, he was just as capable of taking over the Gnostic image of the Church as the body of Christ. The diversity of images and typologies which is used to illustrate the relation of Christ and the Church should put us on our guard against over-accentuating one of these images. They are all relative; none expresses totally and adequately the reality of Christ and the Church.

In fact, the author of Ephesians is not content to compare the relation of Christ to the Church to the marriage relationship. He wishes to go on and draw practical applications for the married life of Christian couples. It is here that the questions begin to arise. I would like now to formulate a triple reserve in regard to these applications.

(a) To be sure, Christ's love for the Church implies an ethical imperative, but this imperative is the commandment to love which is the basis of all Christian ethic. Is this imperative addressed any more to the married than to the celibate? Marriage is only one particular domain in which this imperative must be lived. If the comparison between the love of husband and wife and the love of Christ for the Church is drawn too uncritically then there is the danger of thinking that only married people can fully live the Christian life. After what we have just said about celibacy it would be hard to reconcile such an idea with the New Testament. ${ }^{2}$

(b) A second abuse of this passage is that it has often been used to give a Christological basis to male supremacy. As we have already said the predominance of the husband was part of the cultural environment of the early Christians, not one of their creations, and it would be just as well not to apotheosise or eternalise this state of affairs by some sort of Christo-

1 I find that I cannot completely agree with the provocative interpretation of I Cor. vii. 39 , given by J.-J. von Allmen, Maris et femmes d'après saint Paul, Neuchâtel 1951, $18 \mathrm{ff}$.

2 The same thing is to be said against the conception which tries to found the sacramentality of marriage on the task of mutual sanctification (Eph. v. $26 \mathrm{f}$; ; I Cor. vii. I4, 16; cf. B. Reicke, in Novum Testamentum, i (1956), 21-34; E. Schillebeeckx, op. cit., i63), as if this were a privilege of the Christian couple. 
logical special pleading. ${ }^{1}$ That profound saying 'Husbands love your wives as Christ loved the Church', ${ }^{2}$ loses its value, if we read on to find 'The Church submits itself to Christ, women ought therefore in the same manner to submit themselves to their husbands in all things'. No! women ought to love their husbands as Christ loved the Church! Even more than that, all Christians ought to love one another as Christ loved the Church!

(c) My third reserve concerns the tendency to found the indissolubility of marriage on the indissoluble union between Christ and the Church. ${ }^{3}$ This is an improper application. In the first place, the union of a couple does not last beyond death, while the love of Christ for the Church continues throughout eternity. Secondly, that which is true of Christ is not necessarily true of husbands, who, even if they are baptised, remain sinners. We have seen that Jesus does not quote the passage in Genesis in order to show that marriage creates an ontological bond between husband and wife, but rather to say that God wishes that the married couple form one flesh for as long a time as they live. It is for Christian married couples to hear this call founded on Christ's love! There is no state of human life, which is free from the responsibility to obey God.

Let us now ask the same four questions of the patristic literature. ${ }^{4}$

\section{Celibacy ${ }^{5}$}

We have already seen that celibacy for the sake of the Kingdom of God is a new possibility for the Christian life. In some movements this original Christian conception of celibacy is maintained, even in the second century. In fact, we find in the tradition of the itinerant Syrian apostles and the Montanist movement that the eschatological aspect was not completely choked out. But in the main stream of Christian tradition during the first centuries we find that the basis of the celibate life begins to change. It is no longer basically determined by a call to the total service of God, it is no longer a life lived in expectation of the eschaton, but rather it now comes to be considered as a superior degree of perfection, attained only by

\footnotetext{
1 E. Schillebeeckx, op. cit., I9I says rightly: 'La suprématie de l'homme ne doit pas être considérée ici comme une sorte de conclusion théologique tirée du mystère du Christ; c'est plutôt cette suprématie, donnée à l'avance et généralement reçue dans les moeurs du temps, qui est mise en relation avec le Seigneur. La différence est énorme!'.

2 This maxim has no parallel in Jewish or pagan ethics; cf. W. Schrage, Die konkreten Einzelgebote in der paulinischen Paränese, Gütersloh 1961, 206 ff.; H. Greeven, in Z.E.E., i (1957), 122.

${ }^{8}$ Cf., for instance, E. Schillebeeckx, op. cit., 129.

- There are few monographs on marriage in the Early Church; see H. Preisker, Christentum und Ehe in den ersten drei Jahrhunderten, Berlin 1927; L. Godefroy, in Dictionnaire de theologie catholique, ix. 2, 2077-2123. Some more specialised studies will be mentioned in the following pages.

${ }^{3}$ See G. Kretschmar, 'Ein Beitrag zur Frage nach dem Ursprung frühchristlicher Askese', Zeitschrift für Theologie und Kirche, lxi (1964) 27-67; H. von Campenhausen, 'Die Askese im Urchristentum', in Tradition und Leben, Tübingen 1960, $114-56$; H. Chadwick, art. 'Encrateia', in Reallexikon für Antike und Christentum, v, 343-65; A. Vööbus, Celibacy a Requirement for Admission to Baptism in the Early Syrian Church, Stockholm 1951.
} 
special people, or even the consequence of a dualist conception of the universe, which devaluates the carnal side of creation. In the first case we find ourselves face to face with a perfectionism which we notice is especially developed in Qumran. In the second case the Christian tradition has been marked by the intellectual atmosphere which belonged to the end of pagan antiquity. The two influences, Jewish and Hellenistic, contributed to give celibacy a false importance. They were responsible for a double standard of morals, which divided Christians into two classes. The first-class Christians were monks; the second-class Christians were married.

Let us rapidly regard several facts. One notices already during the time of the Apostolic Fathers that those who were 'pure according to the flesh' received growing esteem. In fact, Ignatius of Antioch found it necessary to warn them against thinking that they were better than the bishop. ${ }^{1}$ The Shepherd of Hermas tells us of having received the order to consider his wife as being a sister from that time on, that is, he was to live with her in a life of continence. ${ }^{2}$ II Clement requires the celibate life of all Christians. ${ }^{3}$ In several of the apocryphal Acts, the preaching of the Gospel culminates in an appeal to live a life of continence. ${ }^{4}$ The apostles, we are told, had great success. Many converts were led to live a life without sex, ${ }^{5}$ and still more remarkable some were converted on the wedding night itself. ${ }^{6}$ In the Acts of Thomas the mystical element plays its role as well: one does not become married because one is already engaged to Christ.?

From here it is only a short step to believing that corporal existence itself is evil, and this step Marcion and the various Gnostic sects actually took. ${ }^{8}$ We all know with what vehemence Marcion attacked sexuality as having nothing to do with the good God of Jesus Christ. In Christian Gnosticism, the distrust of the flesh expressed itself in two opposite ways: either men adopted the most rigid sort of asceticism or they engaged in religious $^{9}$ or even simply frivolous ${ }^{10}$ libertinism. The Church evidently reacted against such an explicit condemnation of God's creation: sexuality and marriage have a positive value and are willed by God.11

Even though an absolute dualism of the Gnostic sort was rejected by the Church, the Church was more and more open to the influences of the philosophies of the age, especially middle Platonism and then later neoPlatonism which considered the realm of sensible things to be inferior to

\footnotetext{
1 Polycarp, Letter, v. 2 ; cf. I Clem. xxxv, 2.

2 Visio, ii. 2, 3; Mandatum, i. 2; Similitudo, v. 7, I ff.

${ }^{3}$ viii. $4-5$; xii; xiv-xv. I; Eph. $v$ is now used in order to prohibit marriage!

4 For instance Acta Pauli, v; xi.

${ }^{5}$ For instance Acta Petri, xxxiii-xxxiv.

${ }^{6}$ Acta Thomae, xiv f.

${ }^{7}$ xiv; cxxiv; cf. Acta Foh., cxiii. $\quad{ }^{8}$ But see also Tatian, Acta Andreae, etc.

${ }^{9}$ Cf. the hieros gamos of the disciples of the gnostic Marcus.

${ }^{10} \mathrm{Cf}$. Carpocrates. There were Gnostic schools between those extremes: cf. Basilides and his disciples.

11 Already I Tim. iv. 3 f.; Dionysius of Corinth apud Eusebius, Hist. Eccl., iv. 23.7; Iren., Adv. Haer., i, 28; Clement of Alexandria, Strom., iii who gives us many details on the Christian Gnostics.
} 
the realm of the intelligible and religious. The wise Christian separates himself from desire and rises through a spiritual ascension to the pure contemplation of God. In brief, he chooses the royal road of virginity. As is well known, this is the way things were understood by the great Alexandrians, Clement and Origen. ${ }^{1}$ The conviction of the superiority of virginity over married life became a mark of the whole patristic tradition, both eastern and western. It is only necessary to read the numerous works on virginity by so many of the fathers, Cyprian, Ambrose, Jerome, Augustine, Athanasius, Gregory of Nyssa, John Chrysostom and so on. We find this idea institutionalised in monasticism on the one hand, and in the celibate priesthood on the other hand, from the fourth century onward.2 As we shall see this has left the strongest traces in marriage ethics ever since.

One should mention, too, that this over-evaluation of celibacy could not help but provoke certain reactions. Even in the ancient Church we find, not at all to our surprise, that among the Judeo-Christians marriage was the rule, as we see from the Pseudo-Clementine literature. ${ }^{3}$ It is probably a reaction to Hellenistic-Christianity that inspires the remarks of Elchasai when he declares that he hates celibacy and continence and that he required his disciples to become married. ${ }^{4}$ Even the Syrian Didascalia, which seems to have come from a Judeo-Christian background, considers those who preach virginity to be heretics. ${ }^{5}$

To bring this section to an end, I would say that certainly the celibate life ought to be considered an authentic way of living the Christian life, in so far as it is considered as a vocation for the sake of the Kingdom of God. But when it is taken as a requirement either for all Christians or for a privileged group of those who are really capable of following the evangelical call, or for those who exercise the priestly ministry, then it certainly becomes highly questionable.

\section{Adultery, divorce and second marriages}

Concerning the conception of marriage as a total union of the couple implying a fidelity without reserve, there is unanimous agreement between the New Testament and the Early Church. One cannot help but be impressed with the obvious fact that there is almost no evolution in this matter.

1 Clement, as we shall see, has a positive conception of marriage; but nevertheless he prefers celibacy.

${ }^{2}$ On the celibate priesthood which develops slowly and in the West in a different way than in the East, see C.-J. Hefele-H. Leclercq, Histoire des Conciles, ii. 2, Paris 1908, $1321-48$.

${ }^{3}$ Hom., iii. 26, 68; v. 25; Epist. Clem. ad Jac., vii; Epiphanius, Adv. haer., xxx. I8. Cf. H. Schoeps, 'Ehebewertung und Sexualmoral der späteren Judenchristen', Studia Theologica, ii (r949-50), 99-10r.

4 According to Epiphanius, Adv. Haer., xix. I f.

${ }^{5} \mathrm{Ed}$. Funk, vi. ro. It is not possible to speak here of the special form of celibacy which is the 'spiritual marriage' and which flourished in the Early Church. See the bibliography in Religion in Geschichte und Gegenwart, 3 rd ed. vi. $36 \mathrm{I}$, and H. Baltensweiler, op. cit., $175 \mathrm{ff}$. 
(a) It goes without saying that adultery is unanimously condemned. It is not only that it often appears in the catalogues of vices, where it often heads the list, ${ }^{1}$ but, more than that, it begins to be counted in a special group of capital or mortal sins along with idolatry and murder. ${ }^{2}$ Normally, however, with the exception of a few rigorists, such as Tertullian and Hippolytus, ${ }^{3}$ the Church would accept penitent adulterers back into the Church.4

(b) With this problem the teaching of the Early Church on divorce stands in close relationship. Divorce is not permitted. In the case of the separation of a couple on account of adultery, remarriage is, according to the general rule, excluded. The first to express himself on this question is The Shepherd of Hermas. He says that a Christian husband who discovers that his wife has committed adultery ought to send her away, but to remain alone and not to marry another. For his wife might repent after having been put away by her husband and desire to return to him. ${ }^{5}$ So it is because of the possibility of repentance that the man may not remarry. Hermas is not the only one to teach this. Remarriage during the lifetime of a previous marriage partner always remains excluded as we see from Justin, ${ }^{6}$ Athenagoras, ${ }^{7}$ Clement of Alexandria ${ }^{8}$ and Lactantius. ${ }^{9}$ The legislation of the first councils is no less clear as we can see from the canons of the Council of Elvira ${ }^{10}$ and the Council of Arles. ${ }^{11}$ Augustine, in his work De conjugiis adulterinis, follows a painstaking exegesis of both the Gospels and the letters of Paul, which for the Occident left the matter quite precisely stated.

We should notice, however, that there exists a tradition in the Early Church which interpreted the Matthean exception more forcefully. It assumed that adultery was the equivalent of death for the guilty partner; therefore, the remarriage of the innocent partner could be permitted. ${ }^{12}$ It

${ }^{1}$ For instance Shepherd of Hermas, Mand., viii. 3; Aristides, Apol., xv. 4; Theophilus, Ad Autol., ii. 34; already I Cor. vi. 9; Mk. vii. 22 par.; Didache, ii, 2; iii. 3; Barnabas, xix. 4; Pliny, Ep., x. 96. Further texts where adultery is condemned: Hebr. xiii. 4; Justin Martyr, Apol., i. I5; Hippolytus, Ap. Trad., xv; Clement Alex., Strom., ii. I47; Lactantius, Div. Inst., vi. 23, $32 \mathrm{ff}$.

${ }^{2}$ Cf. Pseudo-Clementine, Epist. ad Jac., vii. 8; Hom., iii. 68; Shepherd of Hermas, Mand., iv. 1.2; Origen, De orat., xxviii. Io; Tertullian, De pud., xii. 4 ff. (speaking on the Apostolic Decree; on the question of the ethical interpretation of the Apostolic Decree see G. Resch, Das Aposteldecret, Leipzig 1905).

${ }^{3}$ Tertullian, De pud.; Hippolytus, Ref., x. 12 ; cf. Origen, De orat., xxviii. 10.

- Cf. John viii, I ff.; Shepherd of Hermas, Mand., iv. 1.7-8; Callixtus, according to Tertullian and Hippolytus, loc. cit.; Clement of Alex., Strom., ii. 147.

${ }^{5}$ Mand., iv. 1, 4-8. ${ }^{6}$ Apol., i. 15.5 .

7 Suppl., xxxiii.

- Lactantius, Div. Inst., vi. 23, $30 \mathrm{ff.}{ }^{10}$ Can., 9-1o.

11 Can., Io. Cf. Council of Carthage A.D. 407, Can. 8.

${ }^{12} \mathrm{Cf}$. Origen, Comm. Matth., xiv. $23 \mathrm{f}$. (Origen is against remarriage); Basil, Ep. ad Amphiloc., i. 9 (but cf. ii. 48; Moralia, lxoiii); Epiphanius, Adv. haer., lix; John Chrysostom, Comm. Matth., Hom., xvii; and even in the West: Lactantius, Epitome, lxi; Jerome, $E p$., Lxxvii, 3 ff.; Pollentius, the adversary in Augustine, De conjugiis adulterinis (cf. De fide et operibus, xuorv); Ambrosiaster, Comm. in I Cor., vii. ro. See O. Rousseau, 'Divorce et remariage. Orient et Occident', Concilium, xxiv (1967), 107-25; Pat E. Harrell, Divorce and 
was this tradition which the Eastern Church canonised in the Council in Trullo of 692, which explains the difference in attitude between the occidental and oriental Christians in regard to the remarriage of divorced persons. (The Churches issuing from the Reformation follow, in general, the oriental tradition.)

(c) With regard to the second marriage of a partner after the death of the husband or wife, the fathers of the Early Church were inclined to follow the opinion of the apostle Paul, that is, that the remarriage of a widow or widower is permitted but not recommended. ${ }^{1}$ Only Tertullian ${ }^{2}$ goes so far as to condemn second marriages in his three works dedicated to this subject. ${ }^{3}$ In the last of these works, De monogamia, which comes from his Montanist period, he would like us to see in the condemnation of second marriage the progress made by the new prophecy, over the specific words of the Gospel. ${ }^{4}$ One of his principal arguments is that the bond of marriage is not broken by death, but rather that it lasts unto eternity. ${ }^{5}$ The intransigence of Tertullian is only followed by the Novatians. ${ }^{6}$ Nevertheless, one usually reaffirms the position of the Pastoral Epistles that the clergy ought not to remarry, ${ }^{7}$ and it is considered strictly against the advice of the Church that a Christian should marry or remarry a non-Christian. ${ }^{8}$

To sum up this section, I would say: The requirement of faithfulness in marriage flows from our Lord's commandment to love. Just as the love of Christians one of another ought to be love of a durable quality, so the particular Christian married couple ought to love one another with fidelity. For this reason adultery is condemned in an absolute manner, but for this reason also the divorce and remarriage of divorced persons appear as an unsatisfactory solution, which does not reconcile those who have been separated but rather perpetuates their separation. As we have seen, Christian tradition has held firmly to this teaching which it received from Jesus, and this, I do not think, we have the right to put in question.

Even though the requirement of faithfulness in marriage continues to remain valid, naturally a man or a woman can fall short here. While the Church continues to condemn adultery and discourage divorce, the Church recognises that divorce and misunderstanding of married couples belong to the realities of this world and, because of its pastoral concern, it

Remarriage in the Early Church, Austin, Texas 1967; J. Moingt, 'Le divorce pour motif d'impudicité (Matthieu 5, 32; I9, 9)', Recherches de science religieuse, lvi (1968), 337-84.

${ }^{1}$ Cf. Shepherd of Hermas, Mand., iv. 4. I-2; Clement of Alex., Strom., iii. I 2.82.4-5; Cyril of Jerusalem, Cat., iv. 26; John Chrysostom, Ad viduam juniorem and Peri monandrias; etc.

2 But cf. Athenagoras, Suppl., xxxiii.

${ }^{8}$ Ad uxorem, De exhortatione castitatis, De monogamia.

4 Chap. xiv.

${ }^{5}$ Chap. $x$.

- Cf. Socrates Schol., Hist. Eccl., v. 22; Council of Nicaea, Can. 8.

7 Tertullian, De exhort. cast., vii; De monog., xi; Didascalia, ed. Funk, ii. 2; Augustine, De bono conjugali, xviii; Apostolic Church Order, xvi; xviii.

${ }^{8}$ Especially Tertullian, Ad uxorem, ii; Cyprian, Testimonia, iii. 62; cf. Council of Elvira, Can., xvi-xviii. See J. Köhne, Die Ehen zwischen Christen und Heiden in den ersten christlichen Jahrhunderten, Paderborn 193 r. 
does not abandon those who find themselves in such situations. The exception that we find in the Gospel of Matthew and Paul's acceptance of the division of a mixed marriage in the event that the non-Christian demands such a separation, open a long series of casuistic concessions, many examples of which are to be found in the canon law of both the Occident and the Orient. These never put in question the absolute character of the ethical imperative of faithfulness, but, rather, they take seriously human frailty. The attitude of mercy and pardon is, after all, equally required by the Gospel. We need only remember the story of Jesus and the woman taken in adultery to recognise that this was the attitude of Jesus.

\section{Attitude toward women}

We have already seen that in the New Testament there is a whole area of marriage ethics which has been borrowed from its environment. Beginning with the second century this area starts to enlarge and to take on a philosophical aspect. The 'household duties' of the earliest literature disappear and its place is taken by a whole ethical system such as we find among the Stoics and Platonists of the period-such as marked Hellenistic Judaism, and Philo in particular. ${ }^{1}$ We would expect to find teaching which, faced by the sexual disorders of late antiquity, would recommend chastity (and that with a strong tendency toward asceticism), without denying the value of marriage. We should not forget that at this same period the Church began to idealise virginity; without doubt it was strongly motivated in this by the spirit of the age.

The Christian apologists have already begun to point out the exemplary character of Christian chastity: many believers hold fast to their virginity. It is the ideal Christian life. Even those who are married do not understand their marriage in terms of pleasure but rather as having the sole purpose of bringing children into the world. ${ }^{2}$ It is Clement of Alexandria who makes the synthesis of this teaching. Because he was the most cultivated humanist among the fathers of the early centuries, it was he who found the kindest words for marriage. His judgment is quite positive. But even so we cannot help but notice-and perhaps we cannot help but be disappointed-within what narrow limits Clement recognises the value of marriage. The great reservation which he constantly makes is that conjugal love cannot be an end in itself. Only in procreation is marriage justified. ${ }^{3}$ In order to support his opinion he quotes a phrase of the Stoic philosopher, Musonius: 'The pleasure alone, even if it is enjoyed in a legitimate union, is contrary to the law, to justice, and to reason'. ${ }^{4}$ From this one phrase one can deduce a good part of the marriage ethics of

1 A good summary of marriage ethics in the ancient world is given by $H$. Preisker, op. cit., $13-99$.

2 Athenagoras, Suppl., xxxiii ; Aristides, Apol., xv; Justin Martyr, Apol., i. 14-15; Ignatius of Antioch, Ad Polycarp., v. 2.

s Paed., ii. 83, 90, 95, 105; Strom., ii. 137, 143.

¿ Paed., ii. 99.2. 
Clement of Alexandria. All who seek pleasure in marriage are condemned. 'Marriage for others may find its meaning in a voluptuous joy', says he, 'but for those who practise philosophy, marriage finds its meaning in accordance with the Logos, because it teaches husbands not to treat their wives as lovers by dishonouring their bodies, but to preserve marriage as an aid for the whole of life and for the excellence of virtue and temperance. Much more precious, it would seem to me, than the sowing of wheat and barley thrown upon the earth at the seasonable time is the fruit of that human sowing. In this regard, that farmer is best who scatters his seed with sobriety. ${ }^{1}$ Clement goes on to draw some practical conclusions from his metaphor of the farmer. 'For the husband there is only one time when he may sow the field, and just as for the farmer it is only that moment when the seed can be received with the hope of fruition'. ${ }^{2}$ In other words you are not supposed to go to bed with your wife when she is already pregnant or during the period when she is still nursing a newborn child. ${ }^{3}$

But one must go on to recognise that in spite of this mistrust of sexuality, which it must be admitted was common to all the Church Fathers (as it was already to Hellenistic Judaism), Clement does see the positive sides of marriage. With great attention he enumerates the family cares of the married couple, not to discourage one from entering upon marriage, as indeed some of the later Church fathers such as John Chrysostom and Gregory of Nyssa did, but far more to underline that those who perform these tasks with fidelity deserve a respect for their obedience to the Lord every bit as much as the celibate. ${ }^{4}$ Marriage does not hinder sanctification; on the contrary, the husband and wife are of mutual aid in deepening one another's faith. ${ }^{5}$ It is Clement who has given us that beautiful line: 'Who are those two or three united together in the name of Christ in the midst of whom is to be found the Lord himself? Could it be any other than the husband, the wife and the child?'6

In that which concerns wifely conduct, Clement quite uncritically takes over the ideals of antiquity for the perfect wife and mistress of the household in regard to good manners and proper attire $;^{7}$ and of this, of course, we have already found traces in the New Testament. As a matter of fact, being a bit different from the New Testament, Clement does not teach any longer that above all a woman must be submissive to her husband, but rather he underlines the basic human equality of the two. ${ }^{8}$ The wife, being bound to her husband by the most intimate ties of a profound love, ${ }^{9}$ may well be responsible for the amelioration of her husband $;^{\mathbf{1 0}}$ she is his helpmate, not only in household affairs but in matters of faith as

1 Strom., ii. $143 \cdot 1-3$.

${ }^{2}$ Strom., ii. 102.1.

3 Strom., iii. 72.

4 Strom., iii. $79 \cdot 5-7$, especially vii. $70.7-8$.

5 Strom., iii. 88.2, I08.x, iv. 126.1-2. Cf. Tertullian, $A d$ uxorem, ii. 8.6 ff.

- Strom., iii. 68.1.

'Paed., iii. chap. I I, et passim; cf. Tertullian, De cultu feminarum.

${ }^{8}$ Paed., i. 4 .

Strom., ii. $137.4,140.2$.

10 Paed., iii. 57.3-4. 
well. ${ }^{1}$ This emancipation has, if $I$ am correct, two sources. ${ }^{2}$ For one thing it was the fruit of the preaching of the Gospel itself. Religiously speaking, a woman has the same value as a man, in the eyes of Christians. There are facts which prove this: Jesus was surrounded by women, and Paul found that many of those who were of the greatest aid to him in his ministry were women. Then, too, one recalls the great services rendered to the Church by virgins and widows during the second century, and this was above all true among the various sects. On the other hand, the emancipation of the Christian married wife was much more the work of men such as Clement who knew how, with great profit to the Christian Church, to draw upon the best of the pagan philosophical teaching of his age on marriage and love ${ }^{3}$.

We know quite well that the mistrust of the Church Fathers in regard to sexuality was a reaction against the sexual debauchery of the late Roman empire, with its prostitution, adultery, and, as a consequence, abortion, infanticide, and exposure of infants. In part we know the same problems to-day. Now, however, we have the possibility of being wiser than our Fathers in the faith, by avoiding those positions which are extreme. Our reaction ought to be to raise up the value of marriage instead of blackening all forms of sexuality, which is a gift of the creator. Quite concretely, I mean by this that we ought to get rid of that strange doctrine picked up by the Fathers that procreation is the purpose of marriage-a view which incidentally has once more come to our attention, being found as the basis of the Encyclical Humanae vitae. ${ }^{4}$ Modern means of contraception are not, for the Christian, an invitation to loose morals, but a new means of enabling men and women to undertake marriage in joy and responsibility. ${ }^{5}$

\section{The sacramentality of marriage}

We have already said that it is difficult to claim the sacramentality of marriage on the basis of the New Testament. Now we are going to find that a study of patristic literature leads to the same result. The tradition of a nuptial blessing develops late; in fact, even in the Middle Ages it retains an optional character, and it is still later that we find an ontological interpretation of the indissolubility of marriage. ${ }^{6}$

1 Strom., iii. I08. I.

${ }^{2}$ Cf. J. Leipoldt, Die Frau in der antiken Welt und im Urchristentum, Leipzig 1954.

${ }^{3}$ For instance Musonius, Plutarch.

4 Cf. Casti connubii (Denzinger, 3 Ist ed., $2228 \mathrm{ff}$.), and De finibus matrimonii (ibid. 2295).

${ }_{5}^{5}$ Fortunately, there is a general consensus among protestants: see R. Grimm, Amour et Sexualité, Neuchâtel 1962; Th. Bovet, Ehekunde, Bern 196I-2; G. Barczay, Revolution der Moral?, Zürich 1967; Sex and Morality: a report presented to the British Council of Churches, London 1966; What the Bishops have said about Marriage, London 1968; etc.

'See R.-G. Gerest, 'Quand les chrétiens ne se mariaient pas à l'Eglise', Lumière et Vie, lxxxii (1967), 3-32; E. Schillebeeckx, op. cit., 207-331; K. Ritzer, Formen, Riten und religiöses Brauchtum der Eheschliessung in den christlichen Kirchen des ersten Jahrtausends, Münster 1962 . 
(a) For marriage entered upon according to the contemporary laws, the first generation of Christians gave no additional juridical or liturgical form. All recent historians admit this. ${ }^{1}$ There is a passage in Ignatius of Antioch $^{2}$ and another passage in Tertullian ${ }^{3}$ which have at times been used to prove the contrary, but I think one has to say that these attempts are quite unconvincing. ${ }^{4}$ It is only from the fourth century onwards that we begin to see the clergy participating in marriage festivities. The first text which indicates this, to my knowledge, is a canon of the Council of Neocaesarea, which forbids priests from participating in the celebration of second marriages. ${ }^{5}$ As we find in Augustine, the priest was invited to the wedding as a witness, but no more. ${ }^{6}$ John Chrysostom ${ }^{7}$ and the Ambrosiaster $^{8}$ speak of a benediction given by the priest to the new couple. In the West he has, in addition, the responsibility of veiling the couple-a tradition which we find mentioned by Ambrose $^{9}$ and the Leonine and Gelasian Sacramentaries. ${ }^{10}$ In the Orient, according to the information given us by John Chrysostom and Gregory of Nazianzus, a clergyman aids in crowning the couple and in joining their right hands. ${ }^{11}$ This always remains, however, a private affair within the framework of the family and home. It is only from the beginning of the sixth century that we have a public religious ceremony and then it is to be found in the framework of the mass. ${ }^{12}$ In the Orient it does not occur until the reign of the Byzantine emperor Basil I, at the end of the ninth century. ${ }^{13}$

What, then, must we conclude from these facts of history? First, we have to admit that the Early Church did not conceive a new form of marriage; it simply took over and conventionalised those local rites which it found. Secondly, we see that it is not an ecclesiastical act of blessing which makes a valid Christian marriage, but each marriage, contracted by either Christian or non-Christian according to the ordinary civil laws of a given time and place, is recognised as valid by the Church. ${ }^{14}$ In reality, during long centuries, the religious ceremony of marriage was considered optional rather than obligatory. It was only after the ninth century that in the East the emperor imposed the liturgical celebration of

${ }^{1}$ R.-G. Gerest, op. cit., Io.

${ }^{2}$ Ad Polycarp., v. 2.

${ }^{3}$ Ad uxorem, ii. 8.

4 K. Ritzer, op. cit., 29 ff.; E. Schillebeeckx, op. cit., 2 I 9 ff.; R.-C. Gerest, op. cit., $29 \mathrm{ff}$; J. Koehne, op. cit., $68 \mathrm{ff}$.

5 Clement of Alex., Paed., iii. 63. I cannot be quoted here.

6 Sermo, 332.4.

7 P.G., li. 210 ; liv. 443.

8 P.L., xvii. 238.

- Ambrose, Ep., xix; cf. Paulinus of Nola, Carmen, xxv; Pope Siricius, P.L., xiii. $113^{6}$

${ }^{10}$ Ed. Mohlberg, I $105 \mathrm{ff}$; $1442 \mathrm{ff}$.

${ }^{11}$ Gregory of Nazianzus, Epp., cxciii and ccxxxii; John Chrysostom, P.G., lxii. 546.

${ }^{12}$ C. note Io, above; Nicolas I, P.L., cxix. 978.

13 Procheiros Nomos, tit. 4 .

${ }^{14}$ In one domain, however, the Church was going farther than the civil laws: the Church recognised the validity of slave marriages; see R.-C. Gerest, op. cit., $24 \mathrm{ff}$. 
marriage as a condition of its validity. In the West this step was not taken until the Council of Trent. ${ }^{1}$

(b) In any case it is not, according to the Early Church, the nuptial blessing which makes of marriage a sacrament. How then did the Church come to claim that marriage was a sacrament? The fifth chapter of Ephesians did not inspire this idea, because, in the patristic period at least, it was never used to interpret marriage.

It was Augustine, in his work De bono conjugali, who spoke of the sacrament of marriage for the first time, but what does he mean by this phrase ?2 First of all we note that he does not make any direct allusion to the 'mystery' of Ephes. v. 32. We can better appreciate the meaning of sacramentum in the works of Augustine, if we consider first of all the conception of marriage given in Roman civil law during the late Roman Empire: Nuptias non concubitus, sed consensus facit. ${ }^{3}$ That is, it is the mutual consent of the couple which makes the marriage valid. ${ }^{4}$ Augustine rendered the idea of consent by the word sacramentum which had, in secular Latin, this idea among several other meanings. Nevertheless, the consent which makes the marriage, according to civil law, is placed by Augustine in a Christian framework; and in this context the consent receives a meaning which is quite profound. The commitment of marriage is to last the whole of life. Neither infidelity nor sterility permitted a marriage partner, says Augustine, to break the sacramentum.

For Augustine, then, the sacrament of marriage is nothing other than the ethical imperative of perpetual fidelity, which is derived from the commandment of love preached by Jesus. Augustine is a faithful witness of the teaching on marriage that we find in the New Testament and in the whole of the Early Church. It is only with the eleventh century that, in the West, the perspective changes. It is then that one begins to speak of an ontological union which unites husband and wife in the sacrament of marriage, and which cannot be broken; it is at this time, too, that one begins to number marriage among the seven sacraments. ${ }^{5}$ The fact that this interpretation of the sacramentality of marriage is, historically speaking, so very late, hardly speaks in its favour. ${ }^{6}$

\footnotetext{
1 Father Gerest, in his conclusion, arrives at this statement: 'On étonnerait bien des gens en leur disant qu'un jour peut-être l'Eglise catholique déclarera que le "oui"' de ses fidèles devant Monsieur le Maire suffit pour qu'ils soient mariés et sacramentellement mariés. 'Théologiquement, il n'y a là rien d'impossible'.

2 Cf. B. A. Pereira, La doctrine du mariage selon saint Augustin, Paris 1930; E. Schillebeeckx, op. cit., 249 ff.

${ }^{3}$ Cod'ex Justiniani, Dig. xvii. 30.

4 G. Ambrose, De inst. virg., vi; Basil, Ep., cxcix.

${ }^{3} \mathrm{Cf}$. E. Schillebeeckx, op. cit., $253 \mathrm{ff}, 266 \mathrm{ff}$. On the Eastern conception of the sacramentality of marriage see M. Jugie, in Dictionnaire de theologie catholique, ix. 2.231 7-31; P. Evdokimov, 'Le sacerdoce conjugal', Le mariage, Tours 1966, 75-125.

B It is to be noticed that Roman Catholic research after Vatican II is calling in question the traditional conception of the sacrament of marriage: $c f$. G. Duquoc, 'Le sacrement de l'amour', Le mariage, Tours 1966, 129-84. A report of the World Council of Churches proposes to found marriage rather on the Biblical conception of 'covenant': $c f$. Istina, xii (1967), 207-29.
} 